\title{
A Sanitation Argument for Clean Indoor Air: Meeting a Requisite for Safe Public Spaces
}

\author{
Anthony Joseph Leonardi ${ }^{1 \star \dagger}$ and Asit Kumar Mishra ${ }^{2+}$ \\ ${ }^{1}$ Bloomberg School of Public Health, Johns Hopkins University, Baltimore, MD, United States, ${ }^{2}$ MaREI Centre, Ryan Institute \\ \& School of Engineering, College of Science and Engineering, National University of Ireland Galway, Galway, Ireland
}

Keywords: airborne, SARS-CoV-2, aerosol, HVAC, HEPA, sanitation

\section{INTRODUCTION}

In public health terms, "sanitation" refers to a public health implementation of hygienic standards and practices meant to address transmissible diseases like Malaria and Cholera in industrial and public settings like factories, schools, and resorts (1). We propose the management of air given the current pandemic with an airborne pathogen (2). Sanitation has had a stable history as a primary focus in the field of public health engineering, responsible for potable water, waste management, and control of mosquito breeding-grounds $(1,3)$. Since addressed by a sanitation approach, the

OPEN ACCESS

Edited by:

Fabrizio Bianchi,

Italian National Research Council, Italy

Reviewed by:

Mohammad Alghounaim,

Amiri Hospital, Kuwait

${ }^{*}$ Correspondence: Anthony Joseph Leonardi

aleona10@jhmi.edu

†These authors have contributed equally to this work

Specialty section

This article was submitted to Environmental health and Exposome,

a section of the journal

Frontiers in Public Health

Received: 30 October 2021

Accepted: 06 January 2022

Published: 09 February 2022

Citation:

Leonardi AJ and Mishra AK (2022) A

Sanitation Argument for Clean Indoor

Air: Meeting a Requisite for Safe

Public Spaces.

Front. Public Health 10:805780.

doi: 10.3389/fpubh.2022.805780 effective handling of vector media has made outbreaks and epidemics like the cholera outbreak of 1,911 in New York City unrepeated in the USA (1). However, rarely have pathogens been met with mitigations and public health sanitation measures considering airborne transmission, save for sanitariums and open-air schools for Tuberculosis and the "Fresh Air" movement during the 1918 Influenza Pandemic, which were both caused by pathogens spreading by aerosols (4-6). In such a rare, but notable example in 1918, an open-air hospital in Boston was retrospectively found to benefit the staff by reducing Influenza infection (7). Given our current pandemic, we believe such ventilation measures should be readopted and the air should be sanitized.

As new evidence shows airborne pathogens such as SARS-Cov-2 spread via aerosols, we should refine what is a nebulous attribution of responsibility in mitigating the spread of airborne pathogens indoors and assign it under the purview of public health sanitation and engineering in order to effectively manage indoor air (2). A building's ventilation system is critical to maintaining a healthy work environment (8). Humans breathe in many times more air than our food or water intake-around 6 liters/minute (7). Therefore, we argue for the sanitation of air under the domain of public health environmental engineering, and echo the calls for a necessary paradigm shift via measures such as ventilation and filtration (8).

\section{DISCUSSION}

\section{Generation of Respiratory Aerosols}

Many viruses including SARS-CoV-2 have ample evidence of primarily airborne transmission (8).

Generation of respiratory aerosols is not limited to aerosols generating medical procedures and is observed for many day-to-day activities like breathing, talking, shouting, coughing and sneezing, and singing (9-12). Emissions increase with airflow velocity and speech volume $(13,14)$. The expelled aerosols have a multimodal size distribution: $0.1,0.2-0.8,1.5-1.8$, and 3.5-5.0 microns, while coughing and talking also have modes at 123 microns and 145 microns, respectively, though the large particles during both talking and coughing are still under 5 microns in size (2). Smaller sized aerosols are generated deeper in the respiratory tract (2). 
Most exhaled aerosols are under 5 microns $(15,16)$. Normal breathing produces hundreds to thousands of such particles per liter of exhaled air (16-18). Due to such small size, these particles can be respired (19). For every particle over 100 microns produced during speech, 100 to 1,000 particles under 100 microns in size (10). Blustery expulsions, like a sneeze or a cough, can produce numerous aerosols in a short period, but talking and breathing are continuous action and a cause for greater concern (20), especially when an infectious person does not display symptoms. A minute of loud conversation can produce thousands of droplets every second, of which, about a thousand particles could contain virus and these can remain afloat for 8 mins or more (21).

While a historical 5 micron boundary has cropped up to distinguish between aerosols and droplets, a 100 micron boundary is supported by evidence $(2,22,23)$. Stokes law for small particles subject to laminar flow can provide a simple approximation of their terminal velocity, thus providing an idea of how long they may stay afloat:

$$
u_{p}=\frac{g \rho_{p} d_{p}^{2} C}{18 \eta}
$$

where "g" is the acceleration due to gravity, " $\eta$ " is the dynamic viscosity of air, " $\rho_{\mathrm{p}}$ " is the density of the particle, " $\mathrm{d}_{\mathrm{p}}$ " is the diameter of the particle, and $\mathrm{C}$ is the Cunnigham slip correction factor (to account for slippage, leading to reduced air resistance, relevant when particle size becomes of the order of the mean free path of air molecules) (24). In still air, a 100 micron particle released at a $1.5 \mathrm{~m}$ height can stay in the air for $\sim 5 \mathrm{~s}$, while traversing $\sim 2 \mathrm{~m}$. Similarly, a 10 micron particle can stay suspended for $\sim 17 \mathrm{~min}$, a 5 micron particle for $\sim 33 \mathrm{~min}$ and a 1 micron particle for over $12 \mathrm{~h}(2,17,25)$. A one micron respiratory aerosols is about a thousand times larger than a single virion. It can contain enough of the virus and stay afloat for hours. Studies have found smaller aerosols to be enriched with infectious pathogens $(15,19,26,27)$. Since room air is rarely still, these particles can get further, especially while aided by violent exhalation events like sneezing or coughing (28). Modeling shows that large droplets over 100 micron are only likely to be the dominant mode of infection within $0.2 \mathrm{~m}$ (talking) or $0.5 \mathrm{~m}$ (coughing) of an infectious person (29). This makes sense when you consider that the concentration of exhaled aerosols is highest closest to the source, in this case, the infectious person. Risks of infection from aerosols will be quite high close to the source (2), highest when the infected and the exposed individuals are positioned so close that breathing flows can approach each other's faces, with complex flow interactions, difficult to predict (20).

\section{Summary of Evidence for Airborne Spread of COVID-19}

Greenhalgh et al. (30), succinctly summarized the evidence that strongly indicates COVID-19 is airborne. The following are some key points from their work.

- Long-range transmission of the disease and overdispersion of the basic reproduction number (R0). These are consistent with airborne transmission but cannot be adequately explained depending on droplets and fomites (31).

- Transmission between people who were never in each other's physical presence, as evidenced from outbreaks in quarantine hotels (32).

- Asymptomatic or presymptomatic transmission, where the infectious person is not sneezing or coughing, accounts for 33 to $59 \%$ of transmissions worldwide, indicating mostly airborne transmission and not droplets (33).

- The disease transmits much more easily indoors than outdoors (34), and transmission can be mitigated by good indoor ventilation (35-38).

- Despite strict contract and droplet precautions and use of relevant personal protective equipment (PPE) (against droplets only), nosocomial infections have unfortunately occurred (39).

- Viable SARS-CoV-2 has been detected in the air in laboratory studies $(40,41)$ as well as in spaces with infected occupants, without any so-called aerosol generating medical procedures being undertaken $(42,43)$. Exhalation of infectious aerosols have now been documented in both animal models (44) and in humans (26).

- SARS-CoV-2 has been traced to locations in buildings that could only be reached via aerosols, like air filters in air handling units of hospitals and the air conditioning vents/ducting (45)

- Animal models where transmission of SARS-CoV-2 occurred between animals whose cages were connected by a ducting network that can only be negotiated by aerosols and not droplets (46). It has also been shown in animal models that placing surgical masks around cages of infectious individuals reduced transmission (47). Animal models also show the aerosol exposure more likely leading to more severe disease and efficient transmission $(48,49)$.

Several in-depth post-hoc analysis of outbreaks have shown that transmission was most likely through aerosols, as opposed to droplets or fomites, like, a department store in China (50), a party traveling in buses (51), the Skagit Valley Chorale (52), and the outbreak on the Diamond Princess cruise ship (53).

\section{Mitigation}

Relative humidity of indoor air impacts the equilibrium size of exhaled aerosols particles (and thus how long they are suspended in air and the distance they can traverse), the viability of viruses in the particles, and our immune defenses (mucociliary clearance) (2). A relative humidity of $40-60 \%$ indoors could reduce possibilities of transmission $(54,55)$.

Both the volume of ventilation and air flow patterns in an occupied space have an impact on airborne transmission of viruses $(2,20)$. Good ventilation can improve indoor air quality and benefit health, comfort, and office work performance, while also reducing occurrences of allergic and asthmatic incidents $(56,57)$. It is important to assure that, like food or waterborne diseases, we can reduce risks of airborne diseases through appropriate engineering measures (8). 
Standards recommend minimum ventilation rates for buildings based on either needs for maintaining acceptable indoor air quality (58) or needs for infection prevention (59). The ventilation in a specific building depends on the intended use of the space, like a school, vs. office buildings, vs. residences, vs. hospital wards, due to differences in occupancy density, layouts, hours of occupancy, and infection prevention needs. Type of ventilation system also affects the chances of infection transmission. In an ideal world, when we can be sure of who is infectious, personalized extraction ventilation for infectious persons can dramatically reduce infection transmission risks (20). However, when a virus can be transmitted by persons exhibiting no symptoms, we would have to provide personalized ventilation and personalized extraction to every occupant, which can quickly become prohibitively costly. An increase in ventilation volume need not always correspond with a reduction in risks (60), implying ventilation volume alone should not be used as an indicator for ventilation performance in actual buildings (20).

Improved ventilation has also been related to reduction in SBS (sick building syndrome) symptoms and relative risks of respiratory illness (61), particularly for the elderly (62), improved comfort and lowering sick absence (schools and offices) (63), and improved productivity (even offsetting any additional energy costs) $(64,65)$. Models of infectious disease transmission show that improved ventilation can mitigate outbreaks of influenza (66), seasonal variations in ventilation (less ventilation during winter) can increase risks of airborne disease transmission in classrooms (67), improved air quality reduces transmission risks of several airborne pathogens in clinics (68), and can also reduce disease transmission risks at a city level (69). A disease that is airborne and has epidemic proportions around the world, is tuberculosis and there are several studies linking improvement in ventilation with reduction in risks of tuberculosis infection $(70,71)$.

Measuring room carbon dioxide levels, while not a proxy for infection risks, is a cost-effective tool for identifying poorly ventilated spaces and spaces that have frequent overcrowding, thus indicating places where transmission is likely to occur (58, $72,73)$. Poor indoor air quality, measured with carbon dioxide $\left(\mathrm{CO}_{2}\right)$ as a proxy, has been shown to increase lower respiratory tract infections in children (74), more frequent incidences of common cold (75), and even a pneumococcal outbreak in a correctional facility (76).

\section{Filtration for Indoor Spaces}

While introducing outdoor air and increasing ventilation is a preferred option, it also carries energy and hence economic implications. In such a situation, assuming the existing heating ventilation and air conditioning (HVAC) system can handle better grade filters, choosing high-efficiency filters can mitigate risks of infection while requiring less operational costs than

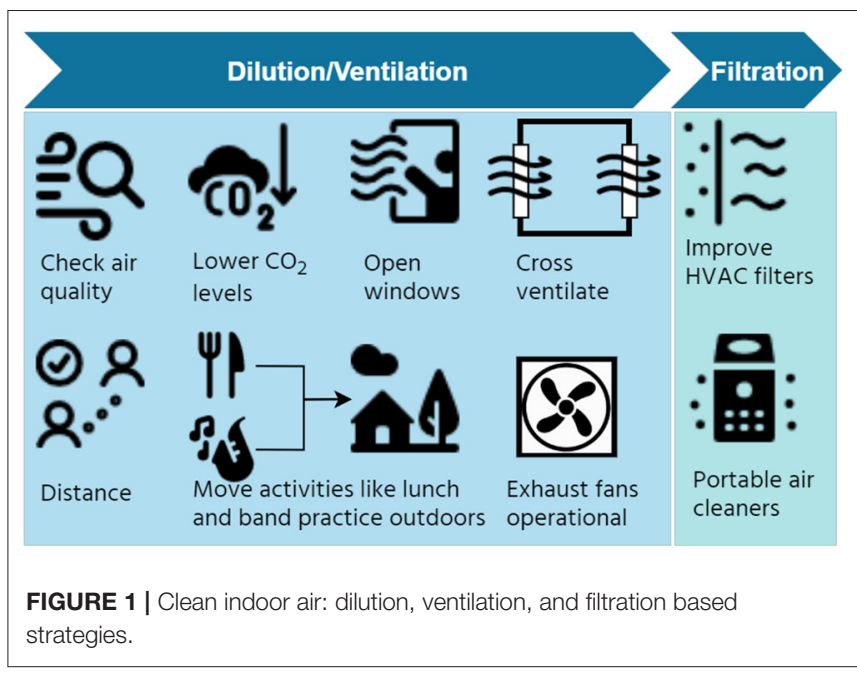

increasing the outdoor air ventilation levels (77). The added cost due to improved filtration can far outweigh the cost of infections.

But changing mechanical ventilation in a building can be expensive and time taking. For such situations and also for buildings without mechanical ventilation, use of portable air cleaners (PACs) can be a quick and affordable option. PACs were already in the market since late 70 s, early 80 s and their use in homes has been increasing, due to a concern with outdoor air quality (78-80). They are part of design recommendations for setting up temporary, negative pressure isolation units (81, 82) and also a part of the WHO Roadmap for ventilation in face of the COVID-19 pandemic (57). Multiple studies during the past months have focused on PACs, due to the ongoing pandemic, and have used approaches CFD modeling (83), experiments in actual spaces (84-88), and study involving actual COVID-19 patients (89) to validate that PACs are an effective mitigation measure. The studies using PACs, to date, have mostly focused on particulate matter pollution (80). Recent studies, cited above, looking at infection mitigation potential have certain limitations in terms of use of different kinds of equipment in different sized spaces, introduction of PACs as part of several other mitigation measures, and few studies that can offer clinical evidence $(85,86,88,89)$. This is an aspect that is gradually starting to gain attention with better designed studies and controlled trials in clinical settings. In the coming years, the noted shortcomings regarding effectiveness of PACs are likely to be comprehensively addressed. The schema in Figure 1 summarizes the mitigation strategies we discuss, centred around improving indoor air quality, through dilution, ventilation, and filtration.

\section{AUTHOR CONTRIBUTIONS}

All authors listed have made a substantial, direct, and intellectual contribution to the work and approved it for publication. 


\section{REFERENCES}

1. Greenberg MR. Sanitation and public health: a heritage to remember and continue. Am J Public Health. (2012) 102:2046. doi: 10.2105/AJPH.2011.300419

2. Tusting LS, Thwing J, Sinclair D, Fillinger U, Gimnig J, Bonner KE, et al. Mosquito larval source management for controlling malaria. Cochrane Database Syst Rev. (2013) 8:CD008923. doi: 10.1002/14651858.CD008923.pub2

3. Fesler DM. Open-air schools. J Sch Nurs Off Publ Natl Assoc Sch Nurses. (2000) 16:20-5. doi: 10.1177/105984050001600303

4. Snider GL. Tuberculosis then and now: a personal perspective on the last 50 years. Ann Intern Med. (1997) 126:23743. doi: 10.7326/0003-4819-126-3-199702010-00011

5. Barry J. The Great Influenza: The Epic Story of the Deadliest Plague in History. Viking. (2004)

6. Hobday RA, Cason JW. The open-air treatment of pandemic influenza. Am J Public Health. (2009) 99 Suppl 2:S236-42. doi: 10.2105/AJPH.2008.134627

7. Norbäck D. An update on sick building syndrome. Curr Opin Allergy Clin Immunol. (2009) 9:55-9. doi: 10.1097/ACI.0b013e32831f8f08

8. Singh HD, Sivakamasundari S. Respiratory minute volume and tidal volume in normal boys. Indian J Pediatr. (1966) 33:391-4. doi: 10.1007/BF02758446

9. Johnson GR, Morawska L, Ristovski ZD, Hargreaves M, Mengersen K, Chao $\mathrm{CYH}$, et al. Modality of human expired aerosol size distributions. J Aerosol Sci. (2011) 42:839-51. doi: 10.1016/j.jaerosci.2011.07.009

10. Duguid JP. The size and the duration of air-carriage of respiratory droplets and droplet-nuclei. Epidemiol Infect. (1946) 44:471-9. doi: 10.1017/S0022172400019288

11. Scheuch G. Breathing is enough: for the spread of influenza virus and SARSCoV-2 by breathing only. J Aerosol Med Pulm Drug Deliv. (2020) 33:2304. doi: 10.1089/jamp.2020.1616

12. Koster F. The experimental aerosol transmission of influenza virus. Future Virol. (2013) 8:969-81. doi: 10.2217/fvl.13.83

13. Asadi S, Wexler AS, Cappa CD, Barreda S, Bouvier NM, Ristenpart WD. Aerosol emission and superemission during human speech increase with voice loudness. Sci Rep. (2019) 9:2348. doi: 10.1038/s41598-019-38808-z

14. Wang CC, Prather KA, Sznitman J, Jimenez JL, Lakdawala SS, Tufekci $Z$, et al. Airborne transmission of respiratory viruses. Science. (2021) 373:6558. doi: 10.1126/science.abd9149

15. Zayas G, Chiang MC, Wong E, MacDonald F, Lange CF, Senthilselvan A, et al. Cough aerosol in healthy participants: fundamental knowledge to optimize droplet-spread infectious respiratory disease management. BMC Pulm Med. (2012) 12:11. doi: 10.1186/1471-2466-12-11

16. Fabian P, Brain J, Houseman EA, Gern J, Milton DK. Origin of exhaled breath particles from healthy and human rhinovirus-infected subjects. J Aerosol Med Pulm Drug Deliv. (2011) 24:137-47. doi: 10.1089/jamp.2010.0815

17. Tang S, Mao Y, Jones RM, Tan Q, Ji JS, Li N, et al. Aerosol transmission of SARS-CoV-2? evidence, prevention and control. Environ Int. (2020) 144:106039. doi: 10.1016/j.envint.2020.106039

18. Shao S, Zhou D, He R, Li J, Zou S, Mallery K, et al. Risk assessment of airborne transmission of COVID-19 by asymptomatic individuals under different practical settings. J Aerosol Sci. (2021) 151:105661. doi: 10.1016/j.jaerosci.2020.105661

19. Fennelly KP. Particle sizes of infectious aerosols: implications for infection control. Lancet Respir Med. (2020) 8:91424. doi: 10.1016/S2213-2600(20)30323-4

20. Ai ZT, Melikov AK. Airborne spread of expiratory droplet nuclei between the occupants of indoor environments: A review. Indoor Air. (2018) 28:50024. doi: 10.1111/ina. 12465

21. Stadnytskyi V, Bax CE, Bax A, Anfinrud P. The airborne lifetime of small speech droplets and their potential importance in SARS-CoV-2 transmission. Proc Natl Acad Sci. (2020) 117:11875-77. doi: 10.1073/pnas.2006874117

22. Prather KA, Marr LC, Schooley RT, McDiarmid MA, Wilson ME, Milton DK. Airborne transmission of SARS-CoV-2. Science. (2020) 370:3034. doi: 10.1126/science.abf0521

23. Wells WF. On air-borne infection. Study II. Droplets and droplet nuclei. Am J Hyg. (1934) 20:611-8. doi: 10.1093/oxfordjournals.aje.a118097
24. Hinds WC. Aerosol Technology: Properties, Behavior, and Measurement of Airborne Particles. London: John Wiley \& Sons (1999).

25. Dey S, Ali SZ, Padhi E. Terminal fall velocity: the legacy of Stokes from the perspective of fluvial hydraulics. Proc R Soc Math Phys Eng Sci. (2019) 475:20190277. doi: 10.1098/rspa.2019.0277

26. Adenaiye OO, Lai J, Mesquita PJB de, Hong F, Youssefi S, German J, et al. Infectious SARS-CoV-2 in Exhaled Aerosols and Efficacy of Masks During Early Mild Infection (2021).

27. Coleman KK, Tay DJW, Sen Tan K, Ong SWX, Than TS, Koh MH, et al. Viral load of severe acute respiratory syndrome coronavirus 2 (SARSCOV-2) in respiratory aerosols emitted by patients with coronavirus disease (COVID-19) while breathing, talking, and singing. Clin Infect Dis. (2021). 21:691. doi: 10.1093/cid/ciab691

28. Tang JW, Bahnfleth WP, Bluyssen PM, Buonanno G, Jimenez JL, Kurnitski $J$, et al. Dismantling myths on the airborne transmission of severe acute respiratory syndrome coronavirus (SARS-CoV-2). J Hosp Infect. (2021) 12:22. doi: 10.1016/j.jhin.2020.12.022

29. Chen W, Zhang N, Wei J, Yen HL, Li Y. Short-range airborne route dominates exposure of respiratory infection during close contact. Build Environ. (2020) 176:106859. doi: 10.1016/j.buildenv.2020.106859

30. Greenhalgh T, Jimenez JL, Prather KA, Tufekci Z, Fisman D, Schooley R. Ten scientific reasons in support of airborne transmission of SARS-CoV-2. The Lancet. (2021) 12:2. doi: 10.1016/S0140-6736(21)00869-2

31. Lewis D. Superspreading drives the COVID pandemic - and could help to tame it. Nature. (2021) 590:544-6. doi: 10.1038/d41586-021-00460-x

32. Eichler N, Thornley C, Swadi T, Devine T, McElnay C, Sherwood J, et al. Transmission of severe acute respiratory syndrome coronavirus 2 during border quarantine and air travel, New Zealand (aotearoa). Emerg Infect Dis. (2021). 27:1274-8. doi: 10.3201/eid2705.210514

33. Johansson MA, Quandelacy TM, Kada S, Prasad PV, Steele M, Brooks JT, et al. SARS-CoV-2 transmission from people without COVID-19 symptoms. JAMA Netw Open. (2021) 4:e2035057. doi: 10.1001/jamanetworkopen.2020.35057

34. Bulfone TC, Malekinejad M, Rutherford GW, Razani N. Outdoor transmission of SARS-CoV-2 and other respiratory viruses: a systematic review. J Infect Dis. (2020) 20:742. doi: 10.1093/infdis/jiaa742

35. Morawska L, Milton DK. It is time to address airborne transmission of coronavirus disease. (COVID-19). Clin Infect Dis. (2020) 71:23113. doi: $10.1093 / \mathrm{cid} / \mathrm{ciaa} 939$

36. WHO. Coronavirus disease (COVID-19): Ventilation and Air Conditioning in public Spaces and Buildings. (2020). Available online at: https://www.who.int/ news-room/q-a-detail/coronavirus-disease-covid-19-ventilation-and-airconditioning-in-public-spaces-and-buildings (accessed January 18, 2021).

37. CDC. Ventilation in Buildings. Centers for Disease Control and Prevention. Published February 9, (2021). Available online at: https://www.cdc.gov/ coronavirus/2019-ncov/community/ventilation.html (accessed March $16,(2021)$.

38. Guo M, Xu P, Xiao T, He R, Dai M, Miller SL. Review and comparison of HVAC operation guidelines in different countries during the COVID-19 pandemic. Build Environ. (2021) 187:107368. doi: 10.1016/j.buildenv.2020.107368

39. Klompas M, Baker MA, Griesbach D, Tucker R, Galagher GR, Lang AS, et al. Transmission of severe acute respiratory syndrome coronavirus 2 (SARSCoV-2) from asymptomatic and presymptomatic individuals in healthcare settings despite medical masks and eye protection. Clin Infect Dis. (2021) 21:218. doi: 10.1093/cid/ciab218

40. van Doremalen N, Bushmaker T, Morris DH, Holbrook MG, Gamble A, Williamson BN et al. Aerosol and surface stability of SARS-CoV2 as compared with SARS-CoV-1. N Engl J Med. (2020) 382:15647. doi: 10.1056/NEJMc2004973

41. Schuit M, Ratnesar-Shumate S, Yolitz J, Williams G, Weaver W, Green B, et al. Airborne SARS-CoV-2 Is Rapidly inactivated by simulated sunlight. J Infect Dis. (2020) 222:564-71. doi: 10.1093/infdis/jiaa334

42. Lednicky JA, Lauzardo M, Fan ZH, Jutla A, Tilly TB, Gangwar M, et al. Viable SARS-CoV-2 in the air of a hospital room with COVID-19 patients. Int J Infect Dis. (2020) 100:476-82. doi: 10.1016/j.ijid.2020.09.025

43. Lednicky JA, Lauzardo M, Alam MM, Elbadry MA, Stephenson CJ, Gibson JC, et al. Isolation of SARS-CoV-2 from the air in a car 
driven by a COVID patient with mild illness. Int J Infect Dis. (2021) 21:603. doi: 10.1101/2021.01.12.21249603

44. Hawks SA, Prussin AJ, Kuchinsky SC, Pan J, Marr LC, Duggal NK. Infectious SARS-CoV-2 Is Emitted in Aerosols (2021).

45. Nissen K, Krambrich J, Akaberi D, Hoffman T, Ling J, Lundkvist A, et al. Long-distance airborne dispersal of SARS-CoV-2 in COVID-19 wards. Sci Rep. (2020) 10:19589. doi: 10.1038/s41598-020-76442-2

46. Kutter JS, de Meulder D, Bestebroer TM, Lexmond P, Mulders A, Richard $\mathrm{M}$, et al. SARS-CoV and SARS-CoV-2 are transmitted through the air between ferrets over more than one meter distance. Nat Commun. (2021) 12:1653. doi: 10.1038/s41467-021-21918-6

47. Chan JFW, Yuan S, Zhang AJ, Poon VKM, Chan CCS, Lee ACY, et al. Surgical mask partition reduces the risk of noncontact transmission in a golden syrian hamster model for coronavirus disease (2019). (COVID-19). Clin Infect Dis Off Publ Infect Dis Soc Am. (2020). 71:2139-49. doi: 10.1093/cid/ciaa644

48. Bixler SL, Stefan CP, Jay A, Rossi F, Ricks KM, Shoemaker CJ, et al. Aerosol exposure of cynomolgus macaques to SARS-CoV-2 results in more severe pathology than existing models. bioRxiv. doi: 10.1101/2021.04.27.441510

49. Port JR, Yinda CK, Owusu IO, Holbrook M, Fischer R, Bushmaker T, et al. SARS-CoV-2 disease severity and transmission efficiency is increased for airborne compared to fomite exposure in Syrian hamsters. Nat Commun. (2021) 12:4985. doi: 10.1038/s41467-021-25156-8

50. Jiang G, Wang C, Song L, Wang X, Zhou Y, Fei C, et al. Aerosol transmission, an indispensable route of COVID-19 spread: case study of a department-store cluster. Front Environ Sci Eng. (2021) 15:46. doi: 10.1007/s11783-021-1386-6

51. Shen $Y$, Li C, Dong $H$, Wang $Z$, Martinez L, Sun $Z$, et al. Community outbreak investigation of SARS-CoV-2 transmission among bus riders in Eastern China. JAMA Intern Med. (2020) 180:1665-71. doi: 10.1001/jamainternmed.2020.5225

52. Miller SL, Nazaroff WW, Jimenez JL, Boerstra A, Buonanno G, Dancer SJ, et al. Transmission of SARS-CoV-2 by inhalation of respiratory aerosol in the Skagit Valley Chorale superspreading event. Indoor Air. (2021) 31:31423. doi: 10.1111 ina. 12751

53. Azimi P, Keshavarz Z, Cedeno Laurent JG, Stephens B, Allen JG. Mechanistic transmission modeling of COVID-19 on the Diamond Princess cruise ship demonstrates the importance of aerosol transmission. Proc Natl Acad Sci. (2021) 118:e2015482118. doi: 10.1073/pnas.2015482118

54. Qian H, Miao T, Liu L, Zheng X, Luo D, Li Y. Indoor transmission of SARS-CoV-2. Indoor Air. (2020) 20:58. doi: 10.1101/2020.04.04.20053058

55. Dabisch P, Schuit M, Herzog A, Beck K, Wood S, Krause M, et al. The influence of temperature, humidity, and simulated sunlight on the infectivity of SARS-CoV-2 in aerosols. Aerosol Sci Technol. (2020) 0:1-12. doi: $10.1080 / 02786826.2020 .1829536$

56. Wargocki P. What we know and should know about ventilation. REHVA J. (2021) 58:5-13

57. WHO. Roadmap to Improve and Ensure Good Indoor Ventilation in the Context of COVID-19. Roadmap to Improve and Ensure Good Indoor Ventilation in the Context of COVID-19. (2021). Available online at: https:// www.who.int/publications/i/item/9789240021280 (accessed March 16, 2021).

58. Persily A. Challenges in developing ventilation and indoor air quality standards: The story of ASHRAE Standard 62. Build Environ. (2015) 91:619. doi: 10.1016/j.buildenv.2015.02.026

59. Sehulster L, Chinn RYW, CDC, HICPAC. Guidelines for environmental infection control in health-care facilities. recommendations of CDC and the Healthcare Infection Control Practices Advisory Committee (HICPAC). MMWR Recomm Rep Morb Mortal Wkly Rep Recomm Rep. (2003) 52(RR10):1-42.

60. Pantelic J, Tham KW. Adequacy of air change rate as the sole indicator of an air distribution system's effectiveness to mitigate airborne infectious disease transmission caused by a cough release in the room with overhead mixing ventilation: a case study. HVACR Res. (2013) 19:94761. doi: $10.1080 / 10789669.2013 .842447$

61. Seppänen OA, Fisk WJ, Mendell MJ. Association of ventilation rates and $\mathrm{CO}_{2}$ concentrations with health andother responses in commercial and institutional buildings. Indoor Air. (1999) 9:226-52. doi: 10.1111/j.1600-0668.1999.00003.x

62. Bentayeb M, Norback D, Bednarek M, Bernard A, Cai G, Cerrai S, et al. Indoor air quality, ventilation and respiratory health in elderly residents living in nursing homes in Europe. Eur Respir J. (2015) 45:122838. doi: 10.1183/09031936.00082414

63. Altomonte S, Allen J, Bluyssen PM, Brager G, Heschong L, Loder A, et al. Ten questions concerning well-being in the built environment. Build Environ. (2020) 180:106949. doi: 10.1016/j.buildenv.2020.106949

64. Wargocki P, Wyon DP. Ten questions concerning thermal and indoor air quality effects on the performance of office work and schoolwork. Build Environ. (2017) 112:359-366. doi: 10.1016/j.buildenv.2016.11.020

65. Ben-David T, Rackes A, Lo LJ, Wen J, Waring MS. Optimizing ventilation: theoretical study on increasing rates in offices to maximize occupant productivity with constrained additional energy use. Build Environ. (2019) 166:106314. doi: 10.1016/j.buildenv.2019.106314

66. Smieszek T, Lazzari G, Salathé M. Assessing the dynamics and control of droplet- and aerosol-transmitted influenza using an indoor positioning system. Sci Rep. (2019) 9:25. doi: 10.1038/s41598-019-38825-y

67. Vouriot CVM, Burridge HC, Noakes CJ, Linden PF. Seasonal variation in airborne infection risk in schools due to changes in ventilation inferred from monitored carbon dioxide. Indoor Air. (2021) 21:12818. doi: 10.1111/ina.12818

68. Zemouri C, Awad SF, Volgenant CMC, Crielaard W, Laheij AMGA, de Soet JJ. Modeling of the transmission of coronaviruses, measles virus, influenza virus, mycobacterium tuberculosis, and legionella pneumophila in dental clinics. $J$ Dent Res. (2020) 99:1192-8. doi: 10.1177/0022034520940288

69. Gao X, Wei J, Lei H, Xu P, Cowling BJ, Li Y. Building ventilation as an effective disease intervention strategy in a dense indoor contact network in an ideal city. PLOS ONE. (2016) 11:e0162481. doi: 10.1371/journal.pone.0162481

70. Du CR, Wang SC, Yu MC, Chiu TF, Wang JY, Chuang PC, et al. Effect of ventilation improvement during a tuberculosis outbreak in underventilated university buildings. Indoor Air. (2020) 30:422-432. doi: 10.1111/ina.12639

71. Matose MT, Poluta M, Douglas TS. Natural ventilation as a means of airborne tuberculosis infection control in minibus taxis. South Afr J Sci. (2019) 115:14. doi: 10.17159/sajs.2019/5737

72. SAGE. SAGE 90 minutes: Coronavirus (COVID-19) response, 27 May 2021. GOV.UK. (2021). Available online at: https://www.gov.uk/government/ publications/sage-90-minutes-coronavirus- covid-19-response-27-may2021/sage-90-minutes-coronavirus-covid-19-response-27-may-2021 (accessed Accessed June 16, 2021).

73. Persily AK. "Indoor carbon dioxide concentrations in ventilation and indoor air quality standards," In: 36th AIVC Conference Effective Ventilation in High Performance Buildings, Madrid, Spain, September 23 (2015).

74. Kovesi T, Gilbert NL, Stocco C, Fugler D, Dales RE, Guay M, et al. Indoor air quality and the risk of lower respiratory tract infections in young Canadian Inuit children. CMAJ. (2007) 177:155-60. doi: 10.1503/cmaj.061574

75. Sun Y, Wang Z, Zhang Y, Sundell J. In China, students in crowded dormitories with a low ventilation rate have more common colds: evidence for airborne transmission. PLOS ONE. (2011) 6:e27140. doi: 10.1371/journal.pone.0027140

76. Hoge CW, Reichler MR, Dominguez EA, Bremer JC, Mastro TD, Hendricks KA, et al. An epidemic of pneumococcal disease in an overcrowded, inadequately ventilated jail. N Engl J Med. (1994) 331:643648. doi: 10.1056/NEJM199409083311004

77. Azimi P, Stephens B. HVAC filtration for controlling infectious airborne disease transmission in indoor environments: predicting risk reductions and operational costs. Build Environ. (2013) 70:150-60. doi: 10.1016/j.buildenv.2013.08.025

78. Shaughnessy RJ, Sextro RG. What is an effective portable air cleaning device? a review. J Occup Environ Hyg. (2006) 3:169-81. doi: 10.1080/15459620600580129

79. Cox J, Isiugo K, Ryan P, Grinshpun SA, Yermakov M, Colleen D, et al. Effectiveness of a portable air cleaner in removing aerosol particles in homes close to highways. Indoor Air. (2018) 28:818-27. doi: 10.1111/ina.12502

80. Rajagopalan S, Brauer M, Bhatnagar A, Bhatt DL, Brook JR, Huang $\mathrm{W}$, et al. Personal-Level protective actions against particulate matter air pollution exposure: a scientific statement from the american heart association. Circulation. (2020) 142:23. doi: 10.1161/CIR.0000000000000931

81. Anderson J, Geeslin A, Streifel A. Airborne Infectious Disease Management: Methods for Temporary Negative Pressure Isolation. Minnoesta, MN: Office of Emergency Preparedness Minnesota Department of Health 
(2007). Available Online at: https://dehs.umn.edu/sites/dehs.umn.edu/files/ airborneweb2_07linked.pdf

82. Mead K, Johnson DL. An evaluation of portable high-efficiency particulate air filtration for expedient patient isolation in epidemic and emergency response. Ann Emerg Med. (2004) 44:635-45. doi: 10.1016/j.annemergmed.2004.07.451

83. He R(何瑞辰), Liu W(刘婉娇), Elson J, Vogt R, Maranville C, Hong $\mathrm{J}$ (洪家荣). Airborne transmission of COVID-19 and mitigation using box fan air cleaners in a poorly ventilated classroom. Phys Fluids. (2021). 33:057107. doi: 10.1063/5.0050058

84. Curtius J, Granzin M, Schrod J. Testing mobile air purifiers in a school classroom: Reducing the airborne transmission risk for SARS-CoV-2. Aerosol Sci Technol. (2021) 55:586-99. doi: 10.1080/02786826.2021.1877257

85. Buising KL, Schofield R, Irving L, Keywood M, Stevens A, Keogh N, et al. Use of portable air cleaners to reduce aerosol transmission on a hospital coronavirus disease. (COVID-19) ward. Infect Control Hosp Epidemiol. (2019) 2021:1-6. doi: 10.1017/ice.2021.284

86. Lee J, Rounds M, McGain F, Schofield R, Skidmore G, Wadlow $\mathrm{I}$, et al. Effectiveness of portable air filtration on reducing indoor aerosol counts: preclinical observational trials. medRxiv. (2021). doi: 10.1101/2021.04.26.21256152

87. Lindsley WG, Derk RC, Coyle JP, Martin SB, Mead KR, Blachere FM, et al. Efficacy of portable air cleaners and masking for reducing indoor exposure to simulated exhaled SARS-CoV-2 aerosols-United States 2021. Morb Mortal Wkly Rep. (2021) 70:972. doi: 10.15585/mmwr.mm7027e1

88. Conway-Morris A, Sharrocks K, Bousfield R, Kermack L, Maes $\mathrm{M}$, Higginson E, et al. The removal of airborne SARS-CoV-2 and other microbial bioaerosols by air filtration on COVID-19 Surge Units. Infectious Dis. (2021) 21:684. doi: 10.1101/2021.09.16.212 63684

89. Parhizkar H, Dietz L, Olsen-Martinez A, Horve P, Bamatan L, Northcutt D, et al. Quantifying human and environmental viral load relationships amidst mitigation strategies in a controlled chamber with participants having COVID-19. In Review. (2021). doi: 10.21203/rs.3.rs$940891 / \mathrm{v} 1$

Conflict of Interest: The authors declare that the research was conducted in the absence of any commercial or financial relationships that could be construed as a potential conflict of interest.

Publisher's Note: All claims expressed in this article are solely those of the authors and do not necessarily represent those of their affiliated organizations, or those of the publisher, the editors and the reviewers. Any product that may be evaluated in this article, or claim that may be made by its manufacturer, is not guaranteed or endorsed by the publisher.

Copyright (c) 2022 Leonardi and Mishra. This is an open-access article distributed under the terms of the Creative Commons Attribution License (CC BY). The use, distribution or reproduction in other forums is permitted, provided the original author(s) and the copyright owner(s) are credited and that the original publication in this journal is cited, in accordance with accepted academic practice. No use, distribution or reproduction is permitted which does not comply with these terms. 